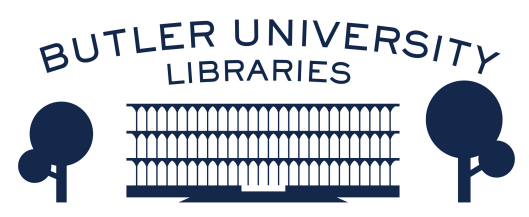

Journal of Hindu-Christian Studies

Volume 18

Article 19

January 2005

\title{
Book Review: "The Graceful Guru: Hindu Female Gurus in India and the United States"
}

Rachel Fell McDermott

Follow this and additional works at: https://digitalcommons.butler.edu/jhcs

Part of the Religion Commons

\section{Recommended Citation}

McDermott, Rachel Fell (2005) "Book Review: "The Graceful Guru: Hindu Female Gurus in India and the United States"," Journal of Hindu-Christian Studies: Vol. 18, Article 19.

Available at: https://doi.org/10.7825/2164-6279.1352

The Journal of Hindu-Christian Studies is a publication of the Society for Hindu-Christian Studies. The digital version is made available by Digital Commons @ Butler University. For questions about the Journal or the Society, please contact cbauman@butler.edu. For more information about Digital Commons @ Butler University, please contact digitalscholarship@butler.edu. 
Mary' in feminist theological discourse" (ix).

The second is in response to contemporary feminist critiques of the religious objectification of women's bodies and of stereotyped gender roles. All three Hindu hymns claim that vision, or gazing upon the goddesses' beauty, both highlights the distinctive nature of the goddesses' power and transforms the viewer; physicality, pleasure, and beauty can be affirmed as spiritually significant. While he is careful to caution that there is no evidence that these Hindu texts were ever used as liberative for human women, "classic goddess texts, even in Sanskrit and by male authors, can be read to good purpose" (13).

The third lesson is the most personal. Clooney invites his readers to think of the goddesses in the Hindu hymns and Mary in the Christian ones as real persons; to become "implicated" and "entangled" in the hymns (23); to share in the state of mind of their authors; and eventually to pray. "The hymns can be used in prayer, and I hope that readers will at least think about what it would mean to use them that way" ( $\mathrm{x}$ ). With translations as beautiful as these, one is indeed moved to "wait with our eyes open for Her arrival" (237):

You are the Lord's left half, so may the loveliness in which both of You delight

and Your auspicious wedding design too come and end the waywardness of my mind, may Your shining feet rule me, and when fierce death comes, may You stand forth (from the Apirami Antati, 72)

Rachel Fell McDermott Barnard College

\section{The Graceful Guru: Hindu Female Gurus in India and the United States. Edited by Karen Pechilis . Oxford: Oxford University Press, 2004, xi + 260 pp.}

IT is a rare pleasure to be treated to a whole book on Hindu female gurus, and this one lives up to the standards one would expect from its fine editor, range of contributors, and publisher. The mandate of the book is to explore "how Hindu female gurus respond to social expectations of femininity and how they are understood to embody the divine; how these two modes intersect in the personae of the gurus; and how their leadership is constituted by the negotiation of the two in distinctive ways" (p. 4). The nine principal chapters acquaint us with ten different guru figures - Sita Devi (Rebecca J. Manring), Gauri Ma (Carol S. Anderson), Anandamayi Ma (Lisa Lassell Hallstrom), Jayashri Ma (June-McDaniel), Mother Meera (Catherine Cornille), Ma Jaya Sati Bhagavati and Karunamayi Ma (Vasudha Narayanan), Shree Ma of Kamakkhya
(Loriliai Biernacki), Ammachi (Selva J. Raj), and Gurumayi (Karen Pechilis) - and these discussions are framed by an excellent introduction by Karen Pechilis and a thought-provoking Afterword by Kathleen M. Erndl. Three of the gurus (Sita Devi, Gauri $\mathrm{Ma}$, and Anandamayi $\mathrm{Ma}$ ) are deceased and lived their entire lives in India; one (Jayashri Ma) currently lives in India; three (Karunamayi $\mathrm{Ma}$, Ammachi, and Gurumayi) travel back and forth between ashramas in India and the West; and three (Ma Jaya Sati Bhagavati, Mother Meera, and Shree Ma of Kamakkhya) have made their permanent homes in the West. Regarding - the last two categories, Pechilis describes Hindu female gurus as a "third wave" of gurus to come to the West, after Swami Vivekananda and Yogananda Paramahamsa, and the gurus of the 1960s and 1970s, like 
Maharshi Mahesh Yogi, Swami Bhaktivedanta, and Rajneesh. As such, the women featured in The Graceful Guru are part of a globalizing and harmonizing Hindu-inspired tradition (p. 10). That this category of female gurus needs exploration is insightfully argued by Pechilis in her Introduction (p. 5): there is no Sanskrit feminine of guru, as we find in yogini, sadhvi, or brahmacarini.

Pechilis in the Introduction, Erndl in her Afterword, and various of the authors in their individual chapters help us think about female gurus in a schematic way. Common themes in the lives of most of the figures include a miraculous birth and childhood; an ability to experience "the Real" continuously; purity; innovations regarding the social expectations of women; association with sakti, and/or the Goddess; and extraordinary charisma. There are, however, aspects of their lives that are not parallel: some receive traditional initiation while others do not; they follow different modes of succession; several seem to be valued for their motherly intimacy, whereas others are aloof and do not manifest a maternal persona; only a few do not uphold conservative Hindu ideas of purity and pollution as regard women's bodies; and some are believed to be human beings who through intense sadhana reached liberation and hence can act as role models, whereas others are said to be avataras or selfrealized from birth and are thus too "other" for emulation.

Critical theory sits lightly on the volume - Biernacki's is the only chapter to employ the insights of a number of Western and feminist theorists to discuss the ways in which Shree Ma "decenters" conventional hierarchies - but this does not mean that The Graceful Guru is naive or "lite." Pechilis, in her essay on Gurumayi, introduces the idea of a "third gender" to try to understand the a-traditional gender of female gurus ( $p$. 222), and several of the authors start with Catherine Wessingerís edited volume, Women's Leadership in Marginal Religions: Explorations outside the Mainstream (1993), and her categorizations of female religious leaders, as points of comparison and contrast. Erndl, in fact, closes her Afterword by underlining one of Wessinger's important points - namely, that the "deemphaisis of an exclusively masculine deity leads to women's leadership institutionally only when there is the social expectation of women's equality" (p. 249).

The category of female guru is complex, and yet there are family resemblances and connections that cause the reader to gain new perspectives on familiar figures who stand in narrative background. For example, one gets a different picture of Sarada Devi, Ramakrishna's wife, from her encouragement of Gauri Ma's efforts in women's education and from the fact that Shree Ma of Kamakkhya is said to be her reincarnation. Likewise, interpreters of Sri Aurobindo, The Mother, and even Ramana Maharshi may be surprised to find that Mother Meera is believed by her disciples to be their spiritual heirs. Gurumayi's guru's guru, Bhagwan Nityananda (d. 1961) is the same teacher who appeared night after night in the early 1970 s to Ma Jaya in her bathroom in Brooklyn. Many Ammachi followers are said to be refugees from Transcendental Meditation or Gurumayi's Siddha Yoga Dham Associates, and the latter's South Fallsburg ashrama contains a hotel which the organization bought from Mahesh Yogi.

Readers of this journal may also be intrigued to find how often female gurus, particularly those in the West, accommodate Christianity and Jesus. Mother Meera recognizes Jesus as an avatara and does not demand that her disciples turn away from him; Ma Jaya calls herself "a strange Hindu who loves Christ" (p. 170); Shree Ma of Kamakkhya had a vision of Jesus at a young age; Ammachi's followers sell souvenir pictures of the child Jesus in her lap, and Ammachi herself, viewed as a "female Christ" (p. 216), willingly gives initiation with a Christ-mantra; and Gurumayi has positioned statues of Saint Francis and Mary in the wooded pathways of her ashrama grounds. Vasudha Narayanan explains this inclusivity and interfaith connection by 
noting that almost all female gurus are not in traditional lineages that wield orthodox power but are "stand-alone" figures who tap into universality and the philosophical oneness of Vedanta.

My one small reservation about this splendid collection of essays is the uneven attention by the authors to the darker sides of the individuals and organizations they describe. For gurus like Sita Devi, Gauri $\mathrm{Ma}$, or Anandamayi Ma, perhaps there are no sources for their more human sides, particularly since two of them were not supposed to be human. I wonder however about the rather idealized picture of Shree Ma of Kamakkhya, she who stands with the dispossessed other, in Biernacki's essay. In the same vein, it takes a small army of devoted disciples to manage and facilitate Ammachi's 1,800 hugs a day; as a guru her innovative maternal ministry may indeed be healing for the recipients, but one also hears stories of the near slavery of those close to her, in terms of work expectations. Again, Pechilisí n. 28 p. 239 on accusations against the SYDA Foundation is so carefully worded as to tell us practically nothing. It is of course an extremely sensitive task to write on current gurus, especially if one has received kindness from them and their followers. Nevertheless, a discussion about what kinds of worries have exercised the disciples and ex-disciples of female gurus could be a fruitful, additional lens through which to understand the group as a whole. In this regard, I find Cornille's essay on Mother Meera to be exemplary. She mentions, up front, discomfitting facts about her subject, and yet her presentation of Mother Meera as a woman who awakens insights in her disciples also makes one take this guru seriously.

These concerns aside, The Graceful Guru is a lovely volume that teaches us a lot about the category of women gurus through interesting descriptions of some famous examples. The volume layout is beautiful, too, with an initial introduction to each of the authors, references and books for further reading collected after each essay, and a final list of websites. If only Oxford had agreed to invest in some photographs!

Rachel Fell McDermott Barnard College

\section{Converting Women: Gender and Protestant Christianity in Colonial South India. Eliza F. Kent. New York: Oxford University Press, 2004, xiv +315 pp.}

\begin{abstract}
ELIZA Kent's study of conversion in the Tamil country of the 19th and early 20th centuries focusses on women -- Western women who were Protestant missionaries, Indian women who converted to Christianity, and issues relating to women's conduct and capacities that were brought into play by these women's propagation of and responses to Christianity. Drawing on an array of Tamil sources, as well as the records and publications in English of missionaries, colonial administrators, and Indian Christians, Kent's effort is to provide an account of the processes and meanings of
\end{abstract}

conversion in terms of the theological, social and political context of these earlier times (as opposed to those of post-Independence India), and an account that reflects the motives and experiences of Indian converts. Given that the Indian converts whose perspectives Kent seeks to recover are not only women, but also frequently low-caste or untouchable, the historiographical challenges are considerable; nonetheless, the endeavour results in a distinctive and extremely valuable contribution.

This book's central thesis is that conversion to Christianity was not the 